\title{
NITRATE CONTENT OF DRINKING WATER AND THEIR EFFECTS ON POPULATION HEALTH
}

\author{
Olena Stadnichuk \\ $\mathrm{PhD}$, Hetman Petro Sahaidachnyi National Army Academy, \\ e-mail: stadnichyk-o@ukr.net, orcid.org/0000-0002-9710-9015, Ukraine \\ Liliia Kropyvnytska \\ Assistant Professor, PhD, Drohobych State Pedagogical University named after Ivan Franko, \\ e-mail: kropliliya@ukr.net, orcid.org/0000-0002-4419-3727, Ukraine \\ Ivan Martyniuk \\ PhD, Hetman Petro Sahaidachnyi National Army Academy, \\ e-mail: ivanmartyn@i.ua, orcid.org/0000-0001-5996-7687, Ukraine \\ Mykola Platonov \\ Senior Researcher, PhD, Hetman Petro Sahaidachnyi National Army Academy, \\ e-mail: nickolas.82@ukr.net, orcid.org/0000-0003-4547-9273, Ukraine \\ Mykola Kucher \\ Hetman Petro Sahaidachnyi National Army Academy, \\ e-mail: nick121@i.ua, orcid.org/0000-0002-7289-3376, Ukraine
}

\begin{abstract}
The problems of drinking water quality have been considered in some settlements of the Turkivskiy district of Lviv region, in particular concerning the content of Nitrogen compounds. 20 sources of decentralized water supply were investigated. It was found that the main hydrochemical indicators of water samples mainly met the requirements for the degree of contamination of hygienic classification of water bodies. At the same time, analyzing the samples for the presence of nitrogen compounds, it was found that in the tested samples: the content of nitrate ions fluctuated within $0,02-016 \mathrm{mg} / \mathrm{dm}^{3}$ (average annual values did not exceed the permissible value); the content of ammonium ions is in the range of $0.5-2.8 \mathrm{mg} / \mathrm{dm}^{3}$, which did not significantly exceed the maximum permissible value. At the time, analysis for $\mathrm{NO}_{3}{ }^{-}$showed an excess of acceptable values in almost all samples by $1.3 \mathrm{y}$ 4.2 times. It was found that the amount of nitrates decreased with the transition from the alluvial aquifers to the indigenous ones, where the average content was $108.9 \mathrm{mg} / \mathrm{dm}^{3}$ and $86.8 \mathrm{mg} / \mathrm{dm}^{3}$, respectively. This is probably due to better protection of the bedrock from surface contamination, greater capacity of the corresponding aquifers and their deeper occurrence. According to the average value of the water pollution index for the nitrate group, the studied objects of decentralized water supply belong to the second class - moderately contaminated. The correlation between the water pollution index by nitrate group and the population morbidity is calculated to be direct and sufficiently high (0.73). The most associated indicators of water quality are diseases of the circulatory system, blood and hematopoietic organs, digestive organs, endocrine and urogenital systems.
\end{abstract}

Keywords: nitrates, drinking water, decentralized water supply, diseases.

DOI: http://dx.doi.org/10.23856/3715 


\section{Introduction}

Contamination of air, water and soil through the introduction of special chemicals (fertilizers, pesticides, insecticides, volatiles and other reagents), which uncontrolled introduction of which leads to the accumulation of nitrogen compounds in soil and water, is a major threat to human life and health. On the one hand, Nitrogen and its compounds are necessary for living organisms, on the other - they can cause a number of diseases. It is well known today that these compounds often have a pronounced toxic effect on the human body, and the quality of drinking water affects human health. Continuous use of water with high nitrate content can lead to various diseases, including methemoglobinemia in children, especially those under 3 years of age (Lototska et al., 2019, Mokienko et al., 2017).

Nitrate pollution is an environmental problem that is nowadays at the forefront and in need of immediate resolution not only for Ukraine but also for many European Union (EU) countries (Sutton, Howard, Erismanetal, 2011). In order to partially address this problem, in 1991, the EU adopted the Nitrates Directive for the protection of groundwater in intensive farming regions. The EU law requires strict adherence to "good professional practice" in agriculture and further measures to reduce the use of chemicals in agricultural practices (Council Directive (91/676 / EEC), UNEP-GEF Project International Nitrogen Management System). All EU Member States must monitor the water bodies on an ongoing basis to verify the effectiveness of the implementation of these programs and submit quarterly reports to the European Commission. Today, only in Germany $60 \%$ of the area has exceeded the limit value for nitrates of $50 \mathrm{mg} / \mathrm{dm}^{3}$ according to the Drinking Water Ordinance (Trinkw, 2001). Groundwater deposits in agricultural land, which are actively used for domestic use, are the most polluted by nitrates (Schadstoffe, 2018; Wasser, 2018).

The National Surface Water Quality Report for 2018 showed that today the negative situation caused by nitrate pollution is characteristic of all regions of Ukraine. However, since January 1, 2019, in accordance with the resolution of the Cabinet of Ministers of Ukraine dated September 19, 2018, No. 758 "On Approval of the Procedure for State Water Monitoring", the Ministry of Agrarian Policy does not monitor agricultural surface waters for the content of harmful substances. According to the same report, in many settlements of Ukraine, in particular in Turka city in the Lviv region, there is no centralized water supply and drainage, and the quality of drinking water does not meet the standards (National Report, 2019). Obviously, the current situation is extremely dangerous and urgent.

The purpose of the study was to conduct studies of the quality of drinking water selected from decentralized water sources within the Turkivskiy district of Lviv region and to assess the risk to human health of drinking water pollution.

The object of the study was natural water from springs, wells used for domestic purposes. To achieve this goal, the following tasks were set: to investigate the state of the objects under study for the content of the main hydrochemical components and to calculate the water pollution index (SOI); to determine the peculiarities of seasonal variations in the concentrations of nitrogen compounds (ammonia, nitrites, nitrates) in the samples tested during 2015-2019; comparison (comparison) of the obtained results with diseases characteristic for the population of Turkivskiy district of Lviv region (based on Pearson correlation coefficients).

Samples were taken in 9 settlements of Turkivskiy district of Lviv region during the rainy period during 2015-2019 (Table 1). Samples No. 1, No. 2, No. 4, No. 5, No. 9, No. 10, No. 12 , No. 13 , No. 16-No. 19 are at a distance of $100 \div 250 \mathrm{~m}$ from existing water bodies, 
the rest at a greater distance $-650 \div 1200 \mathrm{~m}$; №6, №7, № 15 - at a distance of $100 \div 700 \mathrm{~m}$ from the farm. The vast majority of the studied sites belong to aquifers of alluvial deposits $(70 \%)$.

Field studies (direct sampling, determination of organoleptic parameters, rapid test tests) and laboratory methods (study of the content of hydrochemical components in the samples) were used. The selection of water samples and the study of organoleptic and physicochemical parameters of inorganic components were carried out in accordance with standard methods, and the results obtained were compared with the indicators of the physiological completeness of the mineral composition of drinking water, recommended by DSanPiN 2.2.4-171-10 "Guidance requirements for drinking water intended for human consumption".

Table 1

Sampling location and sample number

\begin{tabular}{|c|c|c|c|c|}
\hline $\begin{array}{l}\text { Sample } \\
\text { number }\end{array}$ & Settlement & Location of the object & Aquifers & River basin \\
\hline 1 & Turka city & $49^{\circ} 09^{\prime} 39.3^{\prime \prime} \mathrm{N} 23^{\circ} 01^{\prime} 03.1^{\prime \prime E}$ & alluvial & Litmir River \\
\hline 2 & Turka city & $49^{\circ} 08^{\prime} 57.4^{\prime \prime} \mathrm{N} 23^{\circ} 01^{\prime} 38.9^{\prime \prime E}$ & alluvial & \multirow{2}{*}{ Yablunka River } \\
\hline 3 & Turka city & $49^{\circ} 08^{\prime} 34.2^{\prime \prime} \mathrm{N} 23^{\circ} 02^{\prime} 02.4^{\prime \prime} \mathrm{E}$ & indigenous & \\
\hline 4 & Zavadivka village & $49^{\circ} 08^{\prime} 28.9^{\prime \prime} \mathrm{N} 23^{\circ} 03^{\prime} 48.0^{\prime \prime} \mathrm{E}$ & alluvial & \multirow{2}{*}{ Striy River } \\
\hline 5 & Zavadivka village & $49^{\circ} 08^{\prime} 35.7^{\prime \prime} \mathrm{N} 23^{\circ} 04^{\prime} 02.9^{\prime \prime} \mathrm{E}$ & alluvial & \\
\hline 6 & $\begin{array}{l}\text { VerhniaYablunivka } \\
\text { village }\end{array}$ & $49^{\circ} 09^{\prime} 00.6^{\prime \prime} \mathrm{N} 22^{\circ} 53^{\prime} 37.1^{\prime \prime E}$ & indigenous & \multirow{4}{*}{ Yablunka River } \\
\hline 7 & $\begin{array}{l}\text { VerhniaYablunivka } \\
\text { village }\end{array}$ & $49^{\circ} 08^{\prime} 59.8^{\prime \prime} \mathrm{N} 22^{\circ} 54^{\prime} 08.8^{\prime \prime E}$ & alluvial & \\
\hline 8 & $\begin{array}{l}\text { NizhniaYablunivka } \\
\text { village }\end{array}$ & $49^{\circ} 07^{\prime} 25.8^{\prime \prime} \mathrm{N} 22^{\circ} 56^{\prime} 15.6^{\prime \prime E}$ & indigenous & \\
\hline 9 & $\begin{array}{l}\text { NizhniaYablunivka } \\
\text { village }\end{array}$ & $49^{\circ} 07^{\prime} 30.8^{\prime \prime} \mathrm{N} 22^{\circ} 56^{\prime} 20.9^{\prime \prime} \mathrm{E}$ & alluvial & \\
\hline 10 & Stodilka village & $49^{\circ} 11^{\prime} 24.9^{\prime \prime} \mathrm{N} 23^{\circ} 04^{\prime} 33.4^{\prime \prime E}$ & alluvial & \multirow{5}{*}{ Striy River } \\
\hline 11 & Stodilka village & $49^{\circ} 11^{\prime} 26.0^{\prime \prime} \mathrm{N} 23^{\circ} 04^{\prime} 46.1^{\prime \prime} \mathrm{E}$ & indigenous & \\
\hline 12 & Yavora village & $49^{\circ} 10^{\prime} 43.2^{\prime \prime} \mathrm{N} 23^{\circ} 03^{\prime} 43.9^{\prime \prime} \mathrm{E}$ & alluvial & \\
\hline 13 & Yavora village & $49^{\circ} 10^{\prime} 47.6^{\prime \prime} \mathrm{N} 23^{\circ} 03^{\prime} 09.1^{\prime \prime} \mathrm{E}$ & alluvial & \\
\hline 14 & Yavora village & $49^{\circ} 09^{\prime} 57.9^{\prime \prime} \mathrm{N} 23^{\circ} 04^{\prime} 35.7^{\prime \prime E}$ & indigenous & \\
\hline 15 & Melnichne village & $49^{\circ} 07^{\prime} 06.6^{\prime \prime} \mathrm{N} 23^{\circ} 01^{\prime} 43.4^{\prime \prime} \mathrm{E}$ & indigenous & \multirow{2}{*}{$\begin{array}{l}\text { Melnychanka } \\
\text { River }\end{array}$} \\
\hline 16 & Melnichne village & $49^{\circ} 07^{\prime} 21.3^{\prime \prime} \mathrm{N} 23^{\circ} 02^{\prime} 07.6^{\prime \prime} \mathrm{E}$ & alluvial & \\
\hline 17 & Ilnyk village & $49^{\circ} 05^{\prime} 58.5^{\prime \prime} \mathrm{N} 23^{\circ} 05^{\prime} 58.6^{\prime \prime} \mathrm{E}$ & alluvial & \multirow{2}{*}{ Zavadky River } \\
\hline 18 & Ilnyk village & $49^{\circ} 05^{\prime} 52.6^{\prime \prime} \mathrm{N} 23^{\circ} 05^{\prime} 49.5^{\prime \prime} \mathrm{E}$ & alluvial & \\
\hline 19 & Bitlya village & $48^{\circ} 58^{\prime} 34.9^{\prime \prime} \mathrm{N} 22^{\circ} 59^{\prime} 47.9^{\prime \prime} \mathrm{E}$ & alluvial & \multirow{2}{*}{ Hnyla River } \\
\hline 20 & Bitlya village & $48^{\circ} 58^{\prime} 44.4^{\prime \prime} \mathrm{N} 22^{\circ} 59^{\prime} 44.4^{\prime \prime} \mathrm{E}$ & alluvial & \\
\hline
\end{tabular}

The Water Pollution Index (WPI), as a measure of resistance to water pollution, was calculated by the formula:

$$
W P I=\sum_{i=1}^{n} \frac{C_{i} \cdot M P C_{i}}{n},
$$


where $C$ is the concentration of the regulatory component, $\mathrm{mg} / \mathrm{dm}^{3} ; M P C_{i}$ is the maximum permissible (established) concentration of the component, $\mathrm{mg} / \mathrm{dm}^{3} ; n$ is the number of indicators used to calculate the WPI. Depending on the magnitude of the WPI, drinking water is divided into 5 classes (7 classes are provided for the general characteristics of all types of water) (Snizhko, 2001).

Pearson's formula was used to calculate the correlation coefficient:

$$
P=\frac{\sum(x-\bar{x}) \cdot(y-\bar{y})}{\sqrt{\sum(x-\bar{x})^{2} \cdot(y-\bar{y})^{2}}},
$$

where $x$ and $y$ are the sample averages of AVERAGE (array1) and AVERAGE (array2). Fluctuations in the correlation coefficient between -1 and 1 indicate the inverse and direct correlation between the studied indicators. The value of the correlation coefficient in the range $0.75 \div 1$ indicates a very high, $0.5 \div 0.75$ - high, $0.3 \div 0.5$ - medium and less than $0.3-$ low correlation.

\section{Research results}

Turkivskyi district is a district without large industrial pollutants, the population of which is mainly engaged in forestry (5.3\%) and agrarian (94.4\%) sectors. The magnitude of the technogenic load on the natural environment in the Turka region is the lowest in Lviv region. Mountainous terrain, in turn, also affects the chemical composition of natural waters, the hydrochemical regime of which is characterized by regular changes in the chemical composition or its individual components over time. Changes can be manifested in the form of fluctuations in the concentrations of the constituents of the chemical composition, the level of contamination, runoff of dissolved chemicals, etc. and will be due to the physical and geographical conditions of the basin and anthropogenic influence. (Glovyn, Pavliv, 2018). One source of drinking water pollution, especially during periods of floods and floods, is diffuse runoff from farmland. The danger is water contamination with nitrogen compounds: nitrates, nitrites and ammonium salts. The results of the studies (Table 2) showed there was an excess in some of these indicators.

In general, according to organoleptic indicators, water quality in all studied sources meets the established standards. According to the hydrogen index, samples No. 3, No 4, No 8, No 9, No 11 and No 20 can be considered the most aggressive for chemical and biological processes, resistance to various forms of element migration, and the like.

Conducting an analysis on the hardness of water, it was found that the majority of sources contain moderately hard (15\%), hard (30\%) and very solid (55\%) hard water. A slight excess of the permissible values was recorded by the mineralization of sample No. 12, which is due to the proximity of the Yavorsk hydroelectric power plant. The chloride and sulfate content was within normal limits.

Nitrite ions are not natural components of water, but the likelihood of decentralized water supply in drinking water is very high. This is usually caused by fecal contamination. It was present in almost all the samples tested, but no excesses were observed.

There is some concern about the high content of ammonia ions and nitrate ions in all samples tested. A slight excess of the permissible level for ammonium nitrogen was recorded in samples No. 8, No 15, No 17, and in samples No. 7, No 16, the indicator at the upper limit of the permissible value. Nitrate content exceeds the permitted values by $1.3 \div 4.2$ times in all samples except for samples No. 5, No 6 and No 16. Such excesses are quite dangerous with 
the continued consumption of such water. The amount of nitrates decreases with the transition from the alluvial aquifers to the indigenous ones, where the average content was 108.9 $\mathrm{mg} / \mathrm{dm}^{3}$ and $86.8 \mathrm{mg} / \mathrm{dm}^{3}$, respectively. This is probably due to better protection of the bedrock from surface contamination, greater capacity of the corresponding aquifers and their deeper occurrence.

Table 2

\section{Average hydro-chemical parameters of investigated water samples for 2015-2019}

\begin{tabular}{|c|c|c|c|c|c|c|c|c|c|c|c|}
\hline \multirow{4}{*}{ 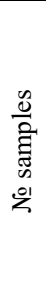 } & \multicolumn{3}{|c|}{ Organolepticindicators } & \multicolumn{8}{|c|}{ Physico-chemical indicators (inorganic components) } \\
\hline & $\begin{array}{l}\text { Smell } \\
\text { points }\end{array}$ & $\begin{array}{c}\text { Colour, } \\
\text { points }\end{array}$ & $\begin{array}{l}\text { Taste, } \\
\text { points }\end{array}$ & $\mathrm{pH}$ & $\begin{array}{l}\text { total } \\
\text { minerali- } \\
\text { sation, } \\
\mathrm{mg} / \mathrm{dm}^{3}\end{array}$ & $\begin{array}{l}\text { Total } \\
\text { hrdness, } \\
\mathrm{mmol} / \mathrm{m}\end{array}$ & $\begin{array}{l}\mathrm{NH}_{4}^{+}, \\
\mathrm{mg} / \mathrm{dm}^{3}\end{array}$ & $\begin{array}{l}\mathrm{NO}_{3}^{-} \\
\mathrm{mg} / \mathrm{dm}^{3}\end{array}$ & $\begin{array}{l}\mathrm{NO}_{2}^{-} \\
\mathrm{mg} / \mathrm{dm}^{3}\end{array}$ & $\begin{array}{l}\mathrm{CL}^{-}, \\
\mathrm{mg} / \mathrm{dm}^{3}\end{array}$ & $\begin{array}{l}\mathrm{SO}_{4}{ }^{2-} \\
\mathrm{mg} / \mathrm{dm}^{3}\end{array}$ \\
\hline & \multicolumn{11}{|c|}{ Normative value indicators according to DSanPiN 2.2.4-171-10 } \\
\hline & $\leq 3$ & $\leq 35$ & $\leq 3$ & $\begin{array}{c}6,5 \\
\div \\
8,5\end{array}$ & $\leq 1500$ & $\leq 10,0$ & $\leq 2,6$ & $\leq 50,0$ & $\leq 3,3$ & $\leq 350$ & $\leq 500$ \\
\hline 1 & 0 & 25 & 1 & 6,8 & 1045 & 5,3 & 0,5 & 151,0 & residue & 21,9 & 145,2 \\
\hline 2 & 0 & 30 & 1 & 7,3 & 1495 & 6,2 & 1,4 & 212,0 & 0,05 & 47,4 & 159,8 \\
\hline 3 & 0 & 15 & 0 & 8,3 & 1340 & 7,6 & 1,2 & 152,3 & 0,11 & 43,3 & 148,6 \\
\hline 4 & 1 & 30 & 2 & 8,8 & 998 & 5,6 & 0,5 & 112,6 & 0,12 & 23,0 & 149,7 \\
\hline 5 & 1 & 20 & 1 & 8,2 & 695 & 4,9 & 1,9 & 47,3 & 0,02 & 26,5 & 198,7 \\
\hline 6 & 1 & 20 & 1 & 7,6 & 615 & 7,1 & 1,7 & 48,5 & residue & 10,2 & 194,2 \\
\hline 7 & 2 & 35 & 3 & 7,9 & 925 & 7,2 & 2,6 & 138,4 & residue & 30,2 & 167,2 \\
\hline 8 & 0 & 30 & 1 & 8,4 & 850 & 6,8 & 3,4 & 85,4 & 0,08 & 39,2 & 100,5 \\
\hline 9 & 1 & 20 & 0 & 8,5 & 1450 & 5,2 & 2,6 & 73,1 & 0,11 & 37,2 & 159,2 \\
\hline 10 & 0 & 25 & 0 & 7,8 & 1380 & 7,8 & 1,7 & 83,1 & 0,08 & 15,7 & 168,2 \\
\hline 11 & 0 & 10 & 1 & 8,2 & 352 & 5,8 & 1,6 & 87,5 & 0,06 & 40,2 & 148,2 \\
\hline 12 & 0 & 15 & 2 & 7,6 & 1750 & 6,4 & 1,2 & 146,2 & 0,13 & 13,7 & 135,2 \\
\hline 13 & 0 & 20 & 2 & 7,1 & 748 & 5,1 & 1,3 & 110,5 & 0,12 & 18,5 & 26,1 \\
\hline 14 & 1 & 15 & 1 & 7,3 & 684 & 4,8 & 1,8 & 67,4 & residue & 44,2 & 168,9 \\
\hline 15 & 2 & 15 & 1 & 7,3 & 425 & 4,4 & 2,7 & 85,5 & 0,13 & 52,3 & 112,3 \\
\hline 16 & 1 & 15 & 3 & 7,8 & 620 & 6,2 & 2,5 & 35,8 & 0,16 & 64,8 & 65,2 \\
\hline 17 & 0 & 25 & 1 & 7,5 & 810 & 8,8 & 2,8 & 120,0 & 0,12 & 10,2 & 139,5 \\
\hline 18 & 1 & 15 & 0 & 7,6 & 650 & 6,5 & 2,2 & 135,0 & 0,04 & 78,8 & 156,3 \\
\hline 19 & 0 & 10 & 2 & 6,2 & 320 & 4,8 & 0,8 & 78,1 & 0,04 & 28,2 & 42,2 \\
\hline 20 & 2 & 10 & 0 & 6,1 & 345 & 4,9 & 1,1 & 87,1 & 0,11 & 46,4 & 30,2 \\
\hline
\end{tabular}

Many of nitrate group compounds were observed in samples near farms and unsatisfactory farms, namely the location of cesspools or sewerage systems.

By average value of WPI by nitrate group, investigated objects of decentralized water supply belong to the second class - moderately contaminated (WPI $=18.1$ ): to the first class (conditionally pure) - 7 samples (samples No. 5, No 6, No 9, No 10, No 14, No 16, No 19) (WPI within $6.0 \div 13.9$ ), to the third class (contaminated) - 2 samples (samples No. 2, No 8) (WPI $-25,4 \div 35,3$ ), to the second class -11 (WPI $-14.6 \div 24.9$ ).

Analyzing the dynamics of changes in the hydrochemical parameters of water for 2015-2019, we can conclude that the content of nitrates in water depends on seasonal fluctuations: the largest - before spring floods, the smallest - in summer, which is consistent with our previous studies (Kropyvnytska et al., 2017) and from weather conditions: in dry 
years the groundwater and groundwater levels decreased and the content of all pollutants increased (Kotkova, 2018). In general, nitrate pollution is characteristic of the entire Lviv region. According to the State Institution «Lviv Regional Laboratory Center of the Ministry of Health of Ukraine» 2129 sources of decentralized water supply, which is $15.9 \%$ of the total, were examined to prevent the occurrence of water-nitrate methemoglobinemia in children. Of these, the content of nitrates -2027 , and sanitary standards did not meet -408 .

The correlation coefficient between the degree of environmental pollution and the indicators of quantitative characteristics of health allows to indirectly assess the effect of the chemical composition of water on the health of the population of the Turkiv district (Analytical medical information). The most related indicators of water quality are the data on the incidence of the population for diseases of the blood and hematopoietic organs, digestive organs, endocrine system and others. Previously, we have cited the dependence of cardiovascular disease on water hardness (Stadnichuk, 2019). As the calculations show, the correlation between the water pollution index by nitrate group and population morbidity is quite high (Table 3).

\section{Correlation between water pollution index and population morbidity}

Table 3

\begin{tabular}{|c|c|c|c|c|c|c|}
\hline \multirow[t]{2}{*}{ Morbidity } & \multicolumn{4}{|l|}{ Years } & \multirow{2}{*}{$\begin{array}{l}\text { Correlation } \\
\text { coefficient }\end{array}$} & \multirow{2}{*}{$\begin{array}{l}\text { Degree of } \\
\text { correlation, } \\
\text { type of } \\
\text { connection }\end{array}$} \\
\hline & 2015 & 2016 & 2017 & 2018 & & \\
\hline $\begin{array}{lll}\begin{array}{l}\text { Morbidity } \\
\text { population) }\end{array} & \text { (per } 100,000 \\
\end{array}$ & 1701,3 & 1715,7 & 1726,9 & 1713,7 & 0,73 & High, straight \\
\hline $\begin{array}{l}\text { Diseases of the circulatory } \\
\text { system, } \%\end{array}$ & 31,5 & 32,1 & 32,6 & 33,5 & 1,0 & \multirow[t]{5}{*}{$\begin{array}{l}\text { Very high, } \\
\text { straight }\end{array}$} \\
\hline $\begin{array}{l}\text { Diseases of the blood, } \\
\text { hematopoietic organs and } \\
\text { individual disorders } \\
\text { involving the immune } \\
\text { mechanism, } \%\end{array}$ & 0,99 & 1,08 & 1,15 & 1,13 & 0,91 & \\
\hline Digestive diseases, $\%$ & 6,89 & 7,05 & 7,2 & 7,12 & 0,81 & \\
\hline $\begin{array}{l}\text { Diseases of the endocrine } \\
\text { system, eating disorders, } \\
\text { metabolic disorders, } \%\end{array}$ & 5,1 & 5,32 & 5,46 & 5,29 & 0,81 & \\
\hline Neoplasm, $\%$ & 1,79 & 1,82 & 1,89 & 1,96 & 0,79 & \\
\hline $\begin{array}{l}\text { Diseases of the genitourinary } \\
\text { system, } \%\end{array}$ & 3,67 & 3,87 & 4,01 & 3,79 & 0,67 & High, straight \\
\hline $\begin{array}{lr}\text { Some infectious } & \text { and } \\
\text { parasitic diseases, } \% & \end{array}$ & 1,05 & 1,09 & 1,34 & 1,32 & 0,39 & \multirow[t]{2}{*}{$\begin{array}{l}\text { Medium, } \\
\text { straight }\end{array}$} \\
\hline $\begin{array}{l}\text { Diseases of } \\
\text { musculoskeletal system and } \\
\text { connective tissue, } \%\end{array}$ & 4,8 & 4,7 & 4,65 & 4,96 & 0,34 & \\
\hline $\begin{array}{l}\text { Diseases of the skin and } \\
\text { subcutaneous tissue, } \%\end{array}$ & 2,8 & 2,54 & 2,4 & 2,69 & $-0,68$ & \multirow[t]{3}{*}{ High, reverse } \\
\hline Respiratory, \% & 36,7 & 36,4 & 33,6 & 30,5 & $-0,65$ & \\
\hline Water pollution index & 16,4 & 18,5 & 17,2 & 18,1 & & \\
\hline
\end{tabular}

Nitrate pollution has a negative impact on public health. It is also impossible to reject the facts of their entry into the human body with other sources. In particular, the seasonal 
intake of nitrates in the human body in the spring and autumn periods is several times higher than that coming from water.

Besides detrimental, health of people who directly consume substandard water, the detection of nitrates in groundwater creates a risk of contamination of surface waters of the Stryi River (tributaries of the Dnister River), which are largely fed by groundwater.

\section{Conclusion}

Twenty sources of decentralized water supply, which are located in 9 settlements of the Turkivskiy district of Lviv region, were investigated. The basic hydrochemical indicators of water quality meet the requirements for the degree of contamination of the hygienic classification of water bodies. Nitrogen compounds were detected in the test samples: the content of $\mathrm{NO}_{2}^{-}$ions ranged from $0.02-016 \mathrm{mg} / \mathrm{dm}^{3}$ (average annual values did not exceed the allowed value of $3.3 \mathrm{mg} / \mathrm{dm}^{3}$ ), the content of $\mathrm{NH}_{4}{ }^{+}-$within $0.5-2.8 \mathrm{mg} / \mathrm{dm}^{3}$, which did not significantly exceed the limit value. The most difficult situation is with $\mathrm{NO}_{3}^{-}$, where the exceedance of the permissible values was almost $1.3 \div 4.2$ times in almost all samples. The amount of nitrates decreases with the transition from the alluvial aquifers to the indigenous ones, where the average content was $108.9 \mathrm{mg} / \mathrm{dm}^{3}$ and $86.8 \mathrm{mg} / \mathrm{dm}^{3}$, respectively. This is probably due to better protection of the bedrock from surface contamination, greater capacity of the corresponding aquifers and their deeper occurrence. A large number of nitrate group compounds were observed in samples located near farms and unsatisfactory farms, namely the location of cesspools or sewerage systems.

According to the average value of the water pollution index for the nitrate group, the studied objects of decentralized water supply belong to the second class - moderately contaminated.

The correlation between the water pollution index by nitrate group and the population morbidity is calculated to be direct and sufficiently high (0.73). The most related indicators of water quality are diseases of the circulatory system, blood and hematopoietic organs, digestive organs, endocrine and urogenital systems, neoplasms.

The results of the analysis show that there is a link between the chemical composition of drinking water and the state of health of the population. The negative impact of water components on the human body due to the combined action of its components and is complex. The study of the relationship and mechanism of such changes requires a comprehensive approach, using experimental studies, taking into account the conditions of water use, sanitary characteristics and mineral composition of drinking water, as well as socio-hygienic factors.

\section{References}

About the results of the analysis of monitoring studies of drinking water from the sources of decentralized water supply. (n.d). State Institution «Lviv Regional Laboratory Center of the Ministry of Health of Ukraine». [Electronic resource]. Retrieved from: http://www.ses.lviv.ua/pro-nas/diyalnist/monitorynhovi-doslidzhennya. [in Ukrainian].

Analytical medical information. (n.d). Health Department of the L'viv Regional State Administration. [Electronic resource]. Retrieved from http://www.health-loda.gov.ua /ukr/filess/files.html [in Ukrainian].

Council Directive, 12 Dec. 1991, concerning the protection of waters against pollution caused by nitrates from agricultural sources (91/676/EEC). Official Journal of the European 
Commission, no. L, 375/1. [Electronic resource]. Retrieved from http://eur-lex.europa.eu /legal-content/EN/TXT/PDF/?uri=CELEX:31991L0676\&qid=1487779135312\&from $=$ en. [in English].

Glovyn, N. M., Pavliv, O. V. (2018). The investigation of the qualityof water resources of decentralized water-supply of rural areas in Berezhany district. Scientific Messenger of Lviv National University of Veterinary Medicine and Biotechnologies, 20 (84), 109-114. DOI: 10.15421/nvlvet8420. [in Ukrainian].

Hoivanovych, N. K., Antonyak, H. L., Kossak, H. M. (2018). Monitoring of quality indicators for well waters of Stryi district. Scientific reports of NULES of Ukraine, 5 (75). DOI: 10.31548/dopovidi2018.05.001. [in Ukrainian].

Kotkova, T. N., Fedjuchka, N. I., \& Karas, I. F. (2018). Environmental assessment of drinking water in Luhyny district of Zhytomyr region on chlorides, sulphates and nitrates content. Scientific Bulletin of UNFU, 28(7), 83-87. DOI: 10.15421/40280718. [in English].

Kropyvnytska, L., Stadnichuk, O., Martynyuk, I. (2017). State of the decentralized water supply sources and ways of improving the properties of water. Human health: realities and prospects. Monographic series, Vol. 2, "Health and Environment». Skotna, N. (Ed.). Drohobych: Posvit, 211-220. [in Ukrainian].

Kropyvnytska, L., Stadnichuk, E., Martynyuk, I. (2016). Hydrochemical parameters some natural waters of Turka district, Lviv region and their dependence on seasonal changes. Human health: realities and prospects. Monographic series, Vol. 1, "Promoting healthy lifestyle». Skotna, N. (Ed.). Drohobych: Posvit, 52-59. [in Ukrainian].

Lototska, O. V., Kondratjuk, V. A., Kucher, S. V. (2019). Quality of drinking water as one of the determinants of public health in the western region of Ukraine. Bulletin of social hygiene and health organization of Ukraine, 1 (79), 12-18. DOI: 10.11603/1681-2786.2019.1.10278). [in Ukrainian].

Luoma, H., Aromaa, A., Helminen, S., Murtomaa, H., Kiviluoto, L., Punsar, S., Knekt, P. (1983). Risk of Myocardial Infarction in Finnish Men in Relation to Fluoride, Magnesium and Calcium Concentration in Drinking Water. Acta Medica Scandinavica, Vol. 213, no.3, 171176. DOI:10.1111/j.0954-6820.1983.tb03712.x. [in English].

Mokienko, A.V., Kovalchuk, L.Y., Krissilov, A.D. (2017). Quality of water of surface water bodies as a risk factor for public health: mathematical model. Visn. Nac. Acad. NaukUkr, 10, 42-52. DOI: https://doi.org/10.15407/visn2017.10.042. [in Ukrainian].

Ordinance on the Quality of Water intended for Human Consumption (Trinkwasserverordnung - TrinkwV 2001) as published on 10 March 2016. BGBl. I. [in English]

Schadstoffe. (2018). Nahr- und Schadstoffe. Umweltbundesamt Deutschlands zentrale Umweltbehörde [Electronic resource]. Retrieved from: https://www.umweltbundesamt.de. [in Germany].

Shovkun, T., Myron, I. (2018). The quality of drinking water and its impact on the health of the population of Chernihiv region. Constructive geography and geoecology. Proceedings, no. 1, 167-173. [in Ukrainian].

Snizhko, S. I. (2001). Estimation and prediction of natural water quality. Kyiv: Nika-center. [in Ukrainian].

Stadnichuk, O., Kropyvnytska, L., Kucher, L., Martyniuk, I., Platonov, M. (2019). The Impact of the mineral water composition on the population health. Periodyk naukowy Akademii Polonijnej, 34 (3), 91-98. DOI: 10.23856/3411. [in English] 
Stadnichuk, O., Martyniuk, I., Kropyvnytska, L. (2018). The evaluation of the hydroecosystem (natural waters) toxicity in Turka and Skole districts of Lviv region. Human health: realities and prospects. Monographic series, Vol. 3. «Health and nutrition». Skotna, N. (Ed.). Drohobych: Posvit, 117-13. [in English].

State sanitary norms and rulesare the "Hygienical requirements to the water drinkable, intended for a consumption a man», May, 12, 2010. Order of Ministry of health of Ukraine. Ministry of health of Ukraine, no. 400. [in Ukrainian].

Sutton, M. A., Howard, C.M., Erismanetal, J.W. (Eds.). (2011). The European Nitrogen Assessment: Sources. Effects and Policy Perspectives. Cambridge: Cambridge University Press. [in English].

The National Reporton the Quality of Drinking Water and the State of Drinking Water Supply in Ukraine in 2018 year. (2019). Ministry of Regional Development, Construction and Housing and Communal Services of Ukraine. Kyiv. [in Ukrainian].

UNEP-GEF Project International Nitrogen Management System. (n.d.). INMS. [Electronic resource]. Retrieved from: http://www.inms.international/. [in English].

Wasser. (2018). Nitratim Wasser - so Gefahrlichist Nitratim Trinkwasserwirklich. [Electronic resource]. Retrieved from: https://www.wassertest-online. de. [in Germany]. 